\title{
Decreased expression of CDH1 or CTNNB1 affects poor prognosis of patients with esophageal cancer
}

Hideyuki Ishiguro*, Takehiro Wakasugi, Yukio Terashita, Nobuhiro Sakamoto, Tatsuya Tanaka, Koji Mizoguchi, Hiroyuki Sagawa, Tomotaka Okubo and Hiromitsu Takeyama

\begin{abstract}
Background: E-cadherin/CDH1 is one of the proteins involved in cell adhesion, and it is known that decreased expression of E-cadherin induces lymph node metastasis in esophageal cancer. Beta catenin/CTNNB1, which is an important component of the Wnt signaling pathway, binds to E-cadherin at the cell membrane, where the complex of these two proteins functions in the stabilization of cell adhesion. However, its role in the pathogenesis of esophageal cancer is still unknown.

Methods: This study included 86 patients with esophageal cancer who underwent surgery between 1998 and 2007. The expression of the $E$-cadherin/CDH1 gene product (E-cadherin/CDH1) and that of the beta catenin/CTNNB1 protein in the cell membrane were analyzed by immunohistochemistry. We examined the correlations among CDH1 or CTNNB1 expression, clinicopathological factors, and the prognosis of patients with ESCC.

Results: CDH1 and CTNNB1 were expressed in $52.3 \%$ (45/86) and $36.0 \%$ (31/86) of tumor samples, respectively. Both CDH1 and CTNNB1 were co-expressed in $22.1 \%$ (19/86) of esophageal cancer tissues. CDH1 expression correlated with the $p$-stage (stages I-II vs stages III-IV, $p=0.032)$, T factor (T1-2 vs T3-4, $p=0.0088)$, and lymphatic invasion $(p=0.019)$. However, $\mathrm{CDH} 1$ expression did not correlate with the $N$ factor or the blood vessel invasion. CTNNB1 expression correlated with the $T$ factor (T1-2 vs T3-4, $p=0.0015$ ), $p$-stage (stages I-II vs stages III-IV, $p=0.030$ ), and lymphatic invasion ( $p=0.007)$. The $\mathrm{CDH} 1(+) / C T N N B 1(+)$ phenotype was inversely correlated with the $T$ factor, $N$ factor, $p$-stage, lymphatic invasion, and blood vessel invasion. Furthermore, patients whose tumors were double-positive for $\mathrm{CDH} 1$ and CTNNB1 had a significantly higher survival rate than those whose tumors were negative for CDH1 or CTNNB1 (log-rank test, $p=0.0192$ ). The $T$ factor and $N$ factor had a strong negative correlation with double-positive tumors. These were both independent prognostic factors, as was the double-positive phenotype. A univariate analysis indicated that the $T$ factor, the $N$ factor, and $\mathrm{CDH} 1$ and $\mathrm{CTNNB1}$ co-expression were significant variables that predicted survival (hazard ratio, 2.387; $95 \%$ confidence interval, 1.115-5.102; $p=0.025)$.
\end{abstract}

Conclusions: Decreased expression of CDH1 or CTNNB1 in the cell membranes of cancer cells is associated with poor survival of patients with esophageal cancer.

Keywords: CDH1-CTNNB1, Prognosis, Immunohistochemistry, Esophageal cancer

\footnotetext{
* Correspondence: h-ishi@med.nagoya-cu.ac.jp1

Gastroenterological Surgery, Nagoya City University Graduate School of Medical

Science, 1 Kawasumi, Mizuho-cho, Mizuho-ku, Nagoya 467-8601, Japan
} 


\section{Background}

The prognosis of patients with esophageal cancer remains poor, which highlights the need for the development of new treatment strategies. Today, the overall 5-year survival rate is less than $50 \%$ despite the use of multimodal therapies. To develop novel treatment strategies, it is important to understand the biological behavior of esophageal cancer. Recent studies have found that several genes and molecules are involved in the origin and/or progression of esophageal cancer, including TP53 [1], deleted in esophageal cancer 1 (DEC1) [2], deleted in colorectal cancer (DCC) [3], deleted in lung cancer 1 (DLC1) [4], cyclinD1 [5], and adenomatous polyposis coli (APC) [6]. However, the precise mechanisms that underlie the development and progression of esophageal squamous cell carcinoma (ESCC) are still unclear.

The E-cadherin/CDH1 gene product is a transmembrane protein that is involved in cell adhesion in normal epithelia [7-9]. E-cadherin is also involved in the stabilization of cell adhesion in normal cells and in signal transduction through connections with beta catenin [10]. Beta catenin/CTNNB1, which is a major component of the Wnt signaling pathway, plays an important role in the carcinogenesis of various malignancies. Beta catenin also functions in cell-to-cell adhesion [11-14].

Decreased expression of CDH1 is associated with the poor prognosis of patients with esophageal cancer $[15,16]$. However, the involvement of decreased expression of CTNNB1 at the cell membrane is unclear in metastasis, and the progression of esophageal cancer is unclear.

In this paper, we investigated the clinicopathological significance of $C D H 1$ and CTNNB1 protein expression in the cell membrane and the relation between the coexpression of CDH1 and CTNNB1 in 86 patients with resectable ESCC.

\section{Methods}

\section{Tissue samples}

Samples were obtained from 86 patients with ESCC who underwent surgery at the Department of Gastroenterological Surgery, Nagoya City University Medical School between 1997 and 2005. None of the patients received pre-operative chemotherapy or radiation. The tumors were classified according to the sixth UICC guidelines for clinical and pathological studies on carcinoma of the esophagus. R0/R1 resection was performed on all patients. T4 cases included combined resection of 6 pleuras, 3 pericardia, 11 thoracic ducts, and 4 tracheas because of the invasion of the structure. Stage IV cases included $20 \mathrm{M} 1 \mathrm{a}$ (cervical lymph node metastasis of Ut cases and celiac lymph node metastasis of Lt) and 14M1b (10 non-regional lymph node metastases of Mt cases and 4 lung metastases). We performed combined resection of the partial lung in lung metastasis cases.

\section{Immunohistochemistry}

Immunohistochemical staining was performed on formalin-fixed, paraffin-embedded primary human ESCC tissues using monoclonal anti-E-cadherin (Dako, CA, USA) or anti-beta catenin antibodies (BD Biosciences, Lexington, KY, USA) at dilutions of 1:50 and 1:500, respectively. Paraffin-embedded sections of tumors were deparaffinized, rehydrated, heat-treated by microwaving in $10 \mathrm{mM}$ citrate buffer for $15 \mathrm{~min}$ for antigen retrieval, and cooled to room temperature. The sections were then treated with $0.3 \% \mathrm{H}_{2} \mathrm{O}_{2}$ in methanol for $30 \mathrm{~min}$ to neutralize endogenous peroxidase activity, after which the sections were blocked with normal goat serum for $10 \mathrm{~min}$. Next, the slides were incubated with antibody $\mathrm{H}-100$ overnight at room temperature in a humidified chamber. Immunoreactive proteins were detected by a DAKO Envision System using HRP and DAB, which was followed by a hematoxylin counterstain. Immunostaining for E-cadherin/CDH1 and beta catenin/CTNNB1 was subjectively assessed by two independent investigators (HI and TT), and discordant results were resolved by consultation with a third investigator (TW). In regard to the evaluation of $\mathrm{CDH} 1$ expression, immunostaining was considered positive only when unequivocally strong staining of the cell membrane was present in more than $50 \%$ of the tumor cells, as analyzed by light microscopy. Cases with only faint staining were regarded as negative. For the evaluation of CTNNB1 expression, immunostaining was scored as positive only when unequivocally strong staining of the cell membrane was present in more than $50 \%$ of the tumor cells similar to CDH1. Cases with only faint staining were regarded as negative.

\section{Statistical analysis}

The chi-squared test was used to compare the correlations between clinicopathological factors and the expression of CDH1 and CTNNB1. The cumulative survival rates were calculated according to the Kaplan-Meier method and were compared by the Cox-Mantel test. A multivariate analysis by the Cox proportional hazard risk model was used to obtain the conditional risk of death due to ESCC. Differences were considered statistically significant when $p$ values were less than 0.05 .

\section{Results}

The correlation of clinicopathological factors with the expression of $\mathrm{CDH} 1$ and $\mathrm{CTNNB} 1$

First, we investigated the expression of the CDH1 and CTNNB1 proteins in ESCC tissues by immunohistochemistry. Representative images of cancer tissues immunostained for CDH1 and CTNNB1 are shown in Fig. 1a, b and in Fig. 2a, b, respectively. In normal tissue, both CDH1 and CTNNB1 are strongly expressed. Typical positive cells showed diffuse staining of CDH1 and CTNNB1 

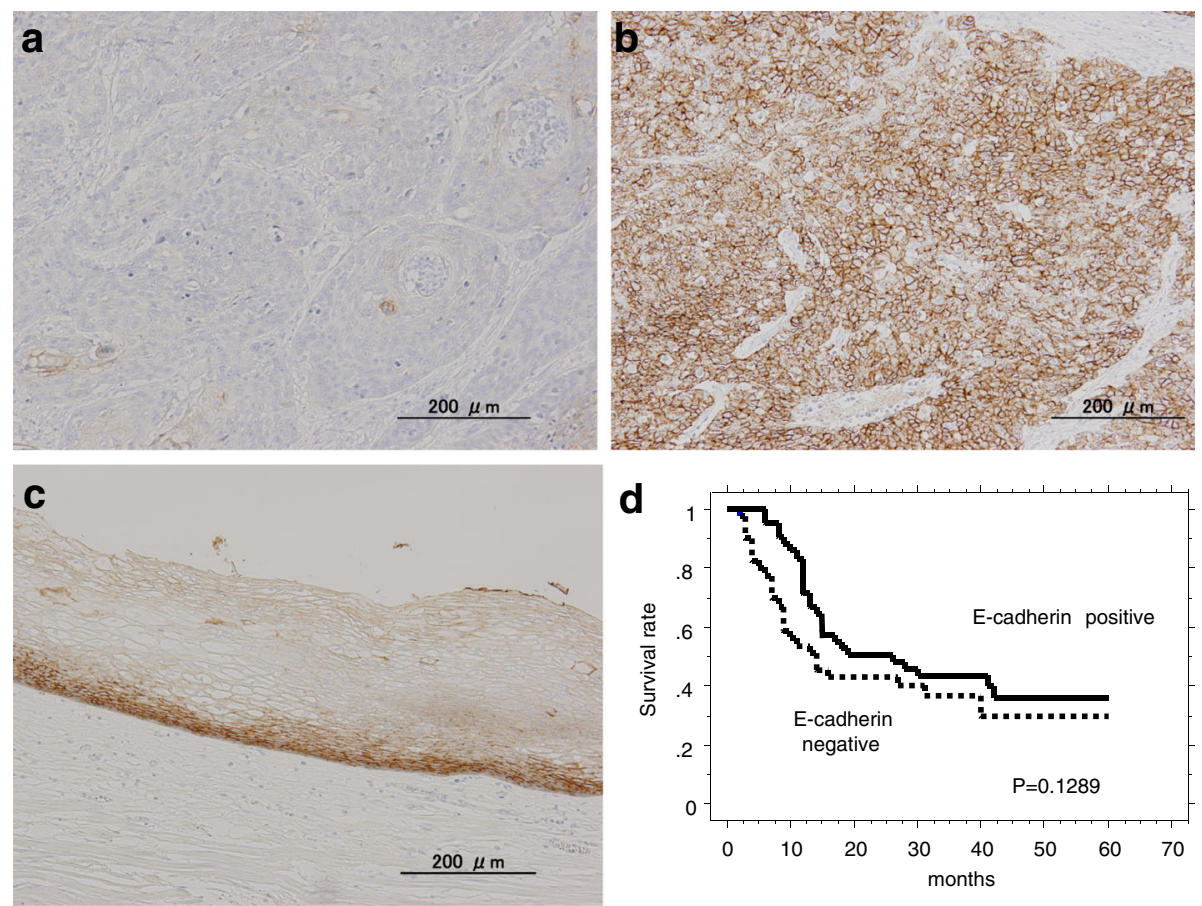

Fig. 1 Representative immunostains for $\mathrm{CDH} 1$ ( $\times 100)$. a Negative $\mathrm{CDH1}$ staining in the cell membrane of tumor cells. b Positive CDH1 staining in the cell membrane of tumor cells. $\mathbf{c}$ Expression of $\mathrm{CDH} 1$ in normal esophageal mucosa. $\mathbf{d}$ Kaplan-Meier survival curve for patients with esophageal cancer whose tumors were classified as either positive or negative for $\mathrm{CDH} 1$ expression by $\mathrm{IHC}$. $\mathrm{CDH} 1$ status did not demonstrate a significant (log-rank, $p=0.1289$ ) relation with patient survival

in the cell membrane. Immunostaining for $\mathrm{CDH} 1$ and CTNNB1 was positive in $52.3 \%(45 / 86)$ and $36.0 \%(31 / 86)$ of patients, respectively (Table 1 ). CDH1 expression correlated with the $p$-stage (stages I-II vs stages III-IV, $p=0.032), T$ factor (T1-2 vs T3-4, $p=0.0088$ ), and lymphatic invasion $(p=0.019)$. However, it did not correlate with the $N$ factor or the $v$ factor. CTNNB1 expression correlated with the $p$-stage (stages I-II vs stages III-IV, $p=0.030)$ and Ly factor $(p=0.007)$ (Table 1). Both CDH1 and CTNNB1 were co-expressed in $22.1 \%(19 / 86)$ of esophageal cancer tissues. The CDH1(+)/CTNNB1(+) phenotype was inversely correlated with the $T$ factor, $N$ factor, $p$-stage, lymphatic invasion, and blood vessel invasion (Table 2). Additionally, no correlations were observed between the expression of $\mathrm{CDH} 1$ and that of CTNNB1 (data not shown).

\section{Survival curves and the expression of $\mathrm{CDH} 1$ and CTNNB1}

Next, we investigated the correlation between positive staining for $\mathrm{CDH} 1$ and $\mathrm{CTNNB} 1$ and the survival of patients with ESCC after surgery. Neither CDH1 nor CTNNB1 exerted a significant effect on patient survival (Figs. 1d and 2d). Indeed, patients whose tumors were positive for $\mathrm{CDH} 1$ by IHC did not demonstrate a significantly longer survival after surgery than patients whose tumors were negative $(26.7 \pm 2.29$ months $(n=45)$ vs $20.9 \pm 2.59$ months $(n=41)$, respectively; $p=0.1289$ by
Log-rank test; Fig. 1d). Moreover, no significant differences were observed with respect to survival after surgery between patients whose tumors were positive and patients whose tumors were negative for CTNNB1 $(27.9 \pm 2.97$ months $(n=31)$ vs $21.5 \pm 2.07$ months $(n=55)$, respectively; $p=0.1743$ by Log-rank test; Fig. 2d). However, the co-expression of CDH1 and CTNNB1 was associated with a significantly longer survival after surgery compared with patients with negative tumors $(p=0.0192)$ (Fig. 3).

A univariate analysis showed that, among the clinicopathological factors examined in this study, the extent of the primary tumor (risk ratio, 6.289; $p<0.001$ ), lymph node metastasis (risk ratio, 5.812; $p<0.001$ ), lymphatic invasion (risk ratio, 5.917; $p=0.003$ ), blood vessel invasion (risk ratio, 3.135; $p=0.002$ ), and positive immunostaining for $\mathrm{CDH}$ and CTNNB1 (risk ratio, 2.387; $p=0.025)$ were statistically significant prognostic factors (Table 3). A multivariate analysis revealed that $\mathrm{CDH} 1$ and CTNNB1 expression was not an independent prognostic factor (data not shown).

\section{Discussion}

The loss of cellular adhesion results in increased invasiveness and metastatic ability of various types of cancer cells. Reduced cellular adhesion has been linked to susceptibility to cancer in some cell types. CDH1 and 

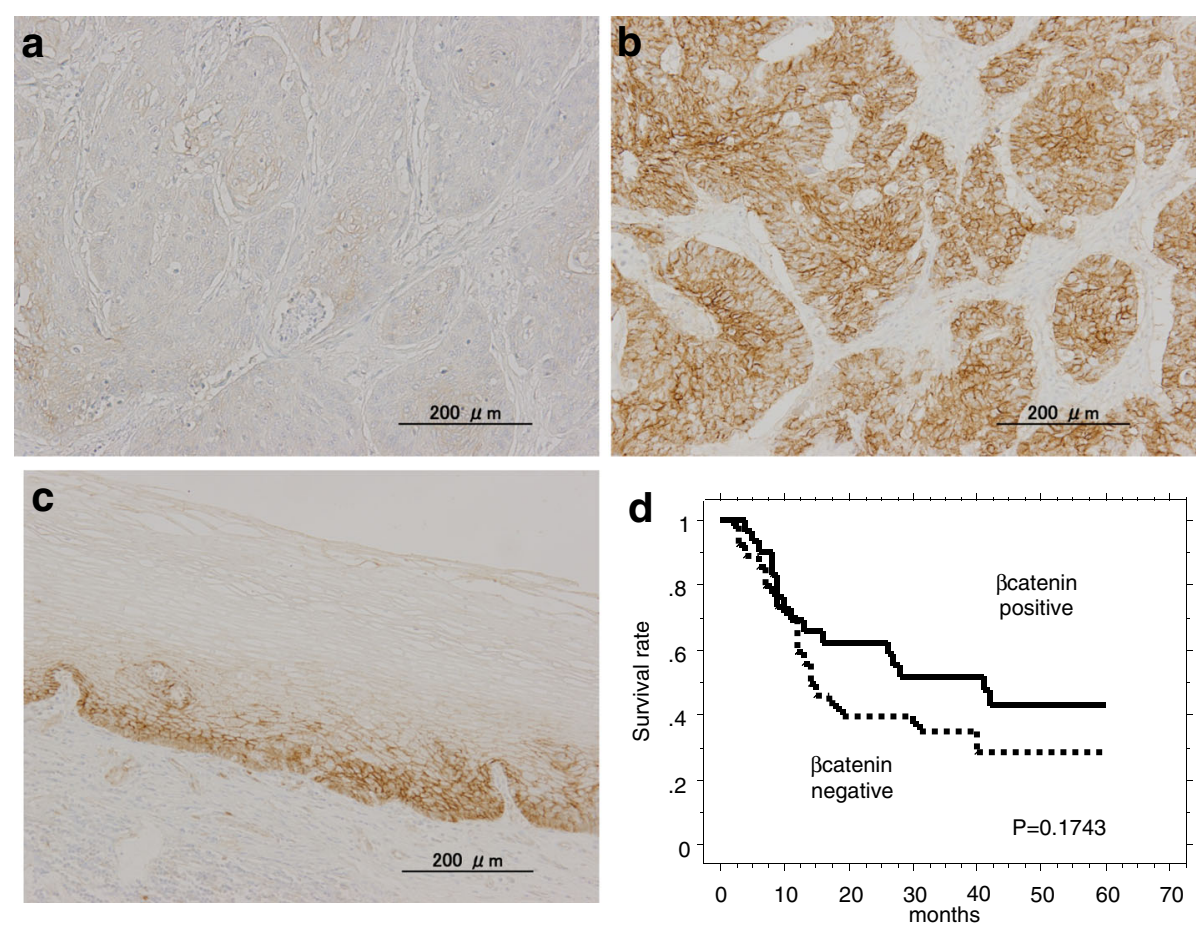

Fig. 2 Representative immunostains for CTNNB1 (x100). a Negative CTNNB1 staining in the cell membrane of tumor cells. b Positive CTNNB1 staining in the cell membrane of tumor cells. $\mathbf{c}$ Expression of CTNNB1 in normal esophageal mucosa. $\mathbf{d}$ Kaplan-Meier survival curve for patients with esophageal cancer whose tumors were classified as either positive or negative for CTNNB1 by IHC. CTNNB1 status did not demonstrate a significant (log-rank, $p=0.1743$ ) relation with patient survival

CTNNB1 are two of the most important determinants of cell polarity and intercellular adhesion. Additionally, the CDH1 and CTNNB1 complex is involved in the maintenance of cell-cell adhesion [10]. In normal cells, the complex is localized to the cell membrane $[17,18]$. Consistent with this finding, our current experiments showed that both CDH1 and CTNNB1 were expressed in the cell membrane in noncancerous cells (Figs. 1c and 2c). Reduced expression of the cadherin-catenin complex in various carcinomas has been reported, and the decreased expression of these proteins has been found to be correlated with high grade and advanced tumor stage, including esophageal carcinoma $[10,19]$.

However, it is still unclear how CDH1 expression is regulated in ESCC. Some factors such as hypermethylation [20], microRNA [21, 22], and PDX1 expression [23], which have been shown to regulate the expression of $\mathrm{CDH} 1$, should be investigated in future studies.

The cytoplasmic and nuclear expression of CTNNB1 is controlled by Wnt-1, APC, and axis inhibitor 1/AXIN1 $[24,25]$. Most of the mutations in $A P C$ result in a truncated APC protein, which can form a complex with but cannot degrade CTNNB1 [24, 26]. The CTNNB1 level in the nucleus may also be increased by mutations in the CTNNB1 gene itself, which may interfere with normal protein degradation $[27,28]$. Thus, a number of mechanisms result in an increased level of CTNNB1, including mutations in the CTNNB1 gene and truncated APC [27, 28]. However, to the best of our knowledge, the mechanism by which CTNNB1 expression is decreased in the cell membrane is still unclear. Few mutations in CTNNB1 and APC occur in the setting of esophageal cancer $[29,30]$. We previously reported that the accumulation of CTNNB1 in the nucleus occurs infrequently in esophageal cancer [31].

The CDH1 gene and the CTNNB1 gene are localized to human chromosomes 16q22.11 [32] and 3p21 [33], respectively. Many studies have suggested that the CDH1 locus (16q) and the CTNNB1 locus (3p) may harbor tumor suppressor genes for prostate cancer [34] and bladder cancer [35]. Therefore, the loss of CDH1 may also contribute to the development of many other types of cancers. Further studies are required to determine whether chromosomal losses occurred in the CDH1 and CTNNB1 loci in the esophageal tumor tissues that were examined in this study.

We analyzed the expression of CDH1 and CTNNB1 by immunohistochemistry. While our results suggested that CDH1 or CTNNB1 expression alone did not affect the prognosis of patients, whether CDH1 and CTNNB1 expression may serve as a good prognostic marker in esophageal cancer is still controversial. In the metaanalysis, there are two reports that $\mathrm{CDH} 1$ expression 
Table 1 Correlation of $\mathrm{CDH} 1$ and CTNNB1 expression by $\mathrm{HC}$ with clinicopathological factors, including patient and tumor characteristics, in esophageal cancer

\begin{tabular}{|c|c|c|c|c|c|}
\hline & & $\begin{array}{l}\text { No. of patients } \\
(n=86)\end{array}$ & & & \\
\hline Characteristics & Case & $\mathrm{CDH} 1(+)$ & $p$ value & CTNNB1(+) & $p$ value \\
\hline \multicolumn{6}{|l|}{ Age at surgery } \\
\hline$<65$ years & 50 & 30 & & 18 & \\
\hline$>65$ years & 36 & 15 & 0.009 & 13 & 0.991 \\
\hline \multicolumn{6}{|l|}{ Gender } \\
\hline Male & 69 & 40 & & 26 & \\
\hline Female & 17 & 5 & 0.035 & 5 & 0.525 \\
\hline \multicolumn{6}{|l|}{ Tumor status } \\
\hline $\mathrm{T} 1$ & 17 & 13 & & 10 & \\
\hline $\mathrm{T} 2$ & 8 & 5 & & 5 & \\
\hline T3 & 37 & 17 & & 9 & \\
\hline T4 & 24 & 10 & & 7 & \\
\hline T1-2 vs T3-4 & & & 0.0088 & & 0.0015 \\
\hline \multicolumn{6}{|c|}{ Lymph node status } \\
\hline NO & 18 & 11 & & 10 & \\
\hline N1 & 68 & 34 & & 21 & \\
\hline N0 vs N1 & & & 0.40 & & 0.053 \\
\hline \multicolumn{6}{|c|}{ Pathological stage } \\
\hline I & 13 & 9 & & 8 & \\
\hline$\|$ & 11 & 8 & & 5 & \\
\hline III & 28 & 15 & & 8 & \\
\hline IV & 34 & 13 & & 10 & \\
\hline I-II vs III-IV & & & 0.032 & & 0.029 \\
\hline \multicolumn{6}{|c|}{ Lymphatic invasion } \\
\hline Negative & 16 & 13 & & 10 & \\
\hline Positive & 54 & 26 & & 14 & \\
\hline Unknown & 16 & & 0.019 & & 0.007 \\
\hline \multicolumn{6}{|c|}{ Blood vessel invasion } \\
\hline Negative & 30 & 19 & & 13 & \\
\hline Positive & 40 & 20 & & 11 & \\
\hline Unknown & 16 & & 0.266 & & 0.167 \\
\hline
\end{tabular}

alone is a valid prognostic marker [36] and aberrant CTNNB1 alone is a prognostic factor [37]. Our data suggested that $\mathrm{CDH}$ alone or CTNNB1 alone did not affect the prognosis of the patients with esophageal cancer, though we could not clarify the discrepancy between their data and ours.

Some clinical studies have reported that CDH1 expression is an indicator of poor prognosis or malignant potential in gastric cancer [38], breast cancer [39], and non-small cell lung cancer [40].

In this study, we found that the decreased expression of $\mathrm{CDH} 1$ or CTNNB1 in the cell membrane in cancer
Table 2 Correlation of CDH1 and CTNNB1 expression by $\mathrm{IHC}$ with clinicopathological factors, including patient and tumor characteristics, in esophageal cancer

\begin{tabular}{|c|c|c|c|}
\hline \multirow[b]{2}{*}{ Characteristics } & \multirow[b]{2}{*}{ Case } & \multicolumn{2}{|l|}{ No. of patients $(n=86)$} \\
\hline & & $\mathrm{CDH} 1(+) / \mathrm{CTNNB1}(+)$ & $p$ value \\
\hline \multicolumn{4}{|l|}{ Age at surgery } \\
\hline$<65$ years & 50 & 14 & \\
\hline$>65$ years & 36 & 5 & 0.119 \\
\hline \multicolumn{4}{|l|}{ Gender } \\
\hline Male & 69 & 17 & \\
\hline Female & 17 & 2 & 0.252 \\
\hline \multicolumn{4}{|l|}{ Tumor status } \\
\hline $\mathrm{T} 1$ & 17 & 8 & \\
\hline $\mathrm{T} 2$ & 8 & 5 & \\
\hline T3 & 37 & 2 & \\
\hline T4 & 24 & 4 & \\
\hline T1 vs T2-4 & & & 0.006 \\
\hline \multicolumn{4}{|c|}{ Lymph node status } \\
\hline No & 18 & 8 & \\
\hline N1 & 68 & 11 & \\
\hline N0 vs N1 & & & 0.010 \\
\hline \multicolumn{4}{|c|}{ Pathological stage } \\
\hline I & 13 & 6 & \\
\hline$\|$ & 11 & 5 & \\
\hline III & 28 & 3 & \\
\hline IV & 34 & 5 & \\
\hline I-II vs III-IV & & & 0.001 \\
\hline \multicolumn{4}{|c|}{ Lymphatic invasion } \\
\hline Negative & 16 & 9 & \\
\hline Positive & 54 & 7 & \\
\hline Unknown & 16 & & 0.003 \\
\hline \multicolumn{4}{|c|}{ Blood vessel invasion } \\
\hline Negative & 30 & 11 & \\
\hline Positive & 40 & 5 & \\
\hline Unknown & 16 & & 0.020 \\
\hline
\end{tabular}

tissues accompanied the local progression and lymph node metastasis of esophageal cancer (Table 2). In addition, patients with lower CDH1 or CTNNB1 expression had a poorer prognosis (Fig. 3). Our data suggested co-expression of CDH1 and CTNNB1 in the cell membrane might be needed for cell stability because cell instability often causes malignant change of the cancer cell.

In patients with esophageal cancer, many prognostic markers, including cyclinD1 and mouse double minute 2 homolog (MDM2), have been reported [41, 42]. Furthermore, we have also reported that survivin [43], pituitary tumor transforming gene 1 (PTTG1) [44], DNA fragmentation factor 45 (DFF45) [45], and DROSHA [46] may be 


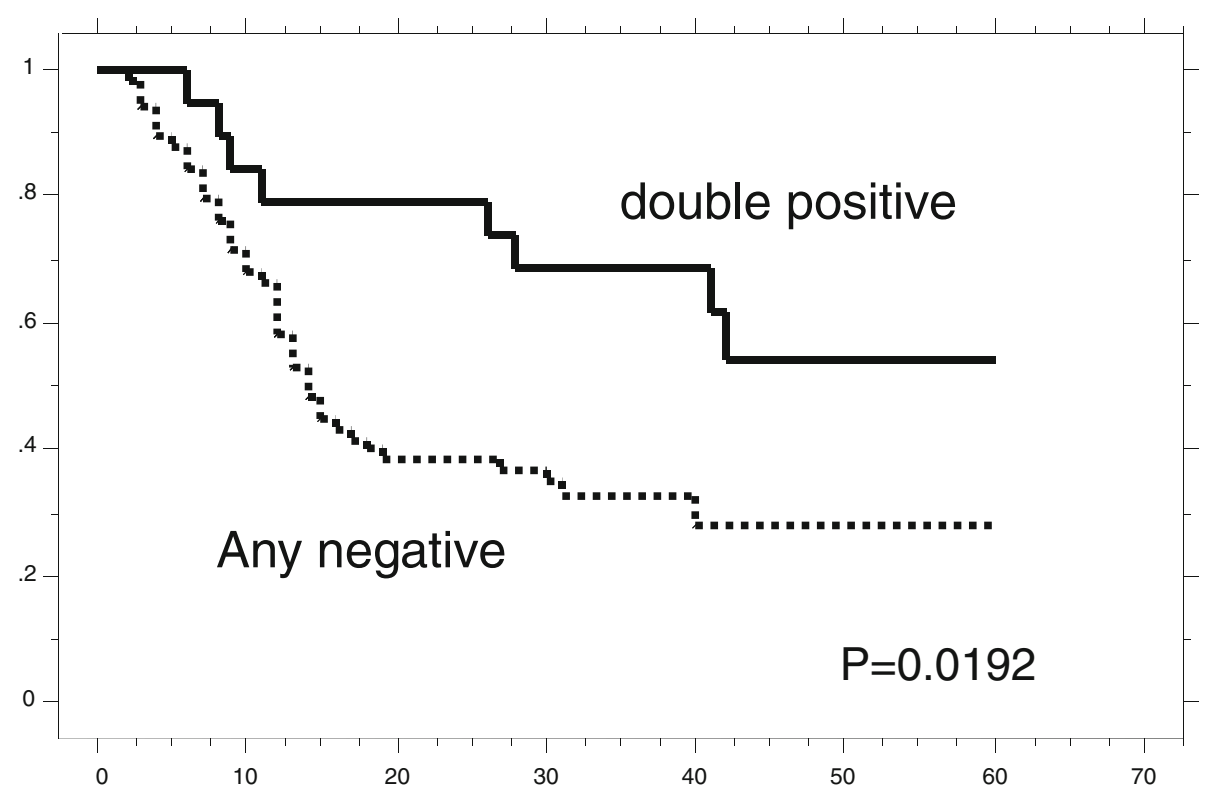

Fig. 3 a Kaplan-Meier survival curve for patients with esophageal cancer whose tumors were classified as either positive or negative for CDH1 and CTNNB1 expression by IHC. Double-positive staining status was found to be strongly associated (log-rank, $p=0.0192$ ) with patient survival

Table 3 Univariate analysis

\begin{tabular}{llll}
\hline Parameter & Risk ratio & $95 \% \mathrm{Cl}$ & $p$ value \\
\hline $\begin{array}{l}\text { Age at surgery } \\
<65 \text { years }\end{array}$ & 1 & & \\
$\quad \begin{array}{l}\text { 65 years } \\
\text { Gender }\end{array}$ & 1.573 & $0.907-2.729$ & 0.107 \\
$\quad$ Female & 1 & & \\
Male & 1.125 & $0.563-2.247$ & 0.739 \\
Primary tumor & & & \\
T1-3 & 1 & & \\
T4 & 6.289 & $3.425-11.49$ & $<0.001$
\end{tabular}

Lymph node metastasis

$\begin{array}{llll}\text { No } & 1 & & \\ \text { N1 } & 5.812 & 2.088-16.39 & <0.001\end{array}$

Lymphatic invasion

$\begin{array}{llll}\text { Negative } & 1 & & \\ \text { Positive } & 5.917 & 1.812-19.23 & 0.003\end{array}$

Venous invasion

Negative 1

$\begin{array}{llll}\text { Positive } & 3.135 & 1.541-6.369 & 0.002\end{array}$

Double-positive immunostaining

\begin{tabular}{llll} 
Negative & 1 & & \\
Positive & 2.387 & $1.115-5.102$ & 0.025 \\
\hline
\end{tabular}

Cl confidence interval prognostic markers of ESCC. Thus, the decreased expression of CDH1 or CTNNB1 represents an additional potential prognostic indicator for patients with ESCC.

Although the precise molecular mechanisms through which $\mathrm{CDH} 1$ or CTNNB1 is downregulated still need to be clarified, our data clearly indicated that the downregulation of $\mathrm{CDH} 1$ or CTNNB1 may be a prognostic marker for ESCC. Finally, these proteins may serve as molecular targets for the development of effective therapeutic agents for patients with esophageal cancer.

\section{Conclusions}

Decreased expression of CDH1 or CTNNB1 in the cell membranes of cancer cells is associated with poor survival of patients with esophageal cancer.

\section{Abbreviations}

APC, adenomatous polyposis coli; AXIN1, axis inhibitor 1; $\mathrm{CDH1}$, cadherin 1; CTNNB1, catenin, beta-1; DCC, deleted in colorectal cancer; DEC1, deleted in esophageal cancer 1; DFF45, DNA fragmentation factor 45; DLC1, deleted in lung cancer 1; ESCC, esophageal squamous cell carcinoma; MDM2, mouse double minute 2 homolog; PTTG1, pituitary tumor transforming gene 1

\section{Acknowledgements}

The authors would like to thank Ms. Seiko Inumaru for her excellent technical assistance.

\section{Funding}

The authors have no kind of profit from any fund.

\section{Availability of data and materials}

The datasets analyzed during the current study are not publicly available because we would like to use it for the comparison between another molecule and $\mathrm{CDH} 1$. However, the datasets are available from the corresponding author on reasonable request. 


\section{Authors' contributions}

$\mathrm{HI}$ analyzed the IHC and was a major contributor of this manuscript. TW was a third investigator of the IHC assessment. YT and NS made the slides of esophageal cancer tissue. TT was an investigator of IHC. KM carried out the statistical analysis. HS and TO performed the surgery. HT was a second contributor of this manuscript. All authors read and approved the final manuscript.

\section{Competing interests}

The authors declare that they have no competing interests.

\section{Consent for publication}

We do not have any individual person's data in our manuscript. Therefore, we state "Not applicable."

\section{Ethics approval and consent to participate}

The authors declare that this study was approved by the ethical committee on human gene research of our institution (No. 71).

\section{Received: 18 February 2016 Accepted: 20 July 2016 Published online: 06 September 2016}

\section{References}

1. Robert V, Michel P, Flaman JM, Chiron A, Martin C, Charbonnier F, Paillot B, Frebourg T. High frequency in esophageal cancers of p53 alterations inactivating the regulation of genes involved in cell cycle and apoptosis. Carcinogenesis. 2000;21:563-5.

2. Nishiwaki T, Daigo Y, Kawasoe T, Nakamura Y. Isolation and mutational analysis of a novel human CDNA, DEC1 (deleted in esophageal cancer 1), derived from the tumor suppressor locus in 9q32. Genes Chromosomes Cancer. 2000;27:169-76.

3. Miyake S, Nagai K, Yoshino K, Oto M, Endo M, Yuasa Y. Point mutations and allelic deletion of tumor suppressor gene DCC in human esophageal squamous cell carcinomas and their relation to metastasis. Cancer Res. 1994:54:3007-10.

4. Daigo Y, Nishiwaki T, Kawasoe T, Tamari M, Tsuchiya E, Nakamura Y. Molecular cloning of a candidate tumor suppressor gene, DLC1, from chromosome 3p21.3. Cancer Res. 1999;59:1966-72.

5. Jiang W, Zhang YJ, Kahn SM, Hollstein MC, Santella RM, Lu SH, Harris CC, Montesano R, Weinstein IB. Altered expression of the cyclin D1 and retinoblastoma genes in human esophageal cancer. Proc Natl Acad Sci U S A. 1993;90:9026-30.

6. Boynton RF, Blount PL, Yin J, Brown VL, Huang Y, Tong Y, McDaniel T, Newkirk C, Resau JH, Raskind WH, et al. Loss of heterozygosity involving the APC and MCC genetic loci occurs in the majority of human esophageal cancers. Proc Natl Acad Sci U S A. 1992:89:3385-8.

7. Takeichi M. The cadherin cell adhesion receptor family: roles in multicellular organization and neurogenesis. Prog Clin Biol Res. 1994;390:145-53.

8. Rimm DL, Morrow JS. Molecular cloning of human E-cadherin suggests a novel subdivision of the cadherin superfamily. Biochem Biophys Res Commun. 1994:200:1754-61

9. Damsky CH, Richa J, Solter D, Knudsen K, Buck CA. Identification and purification of a cell surface glycoprotein mediating intercellular adhesion in embryonic and adult tissue. Cell. 1983;34:455-66.

10. Krishnadath KK, Tilanus HW, van Blankenstein M, Hop WC, Kremers ED, Dinjens WN, Bosman FT. Reduced expression of the cadherin-catenin complex in oesophageal adenocarcinoma correlates with poor prognosis. J Pathol. 1997;182:331-8.

11. Nusse R, Varmus HE. Wnt genes. Cell. 1992:69:1073-87.

12. van den Heuvel M, Nusse R, Johnston P, Lawrence PA. Distribution of the wingless gene product in Drosophila embryos: a protein involved in cell-cell communication. Cell. 1989;59:739-49.

13. Wieschaus E, Riggleman R. Autonomous requirements for the segment polarity gene armadillo during Drosophila embryogenesis. Cell. 1987:49:177-84.

14. Nakamura Y. Cleaning up on beta-catenin. Nat Med. 1997:3:499-500

15. Zhao XJ, Li H, Chen H, Liu YX, Zhang LH, Liu SX, Feng QL. Expression of e-cadherin and beta-catenin in human esophageal squamous cell carcinoma: relationships with prognosis. World J Gastroenterol. 2003;9:225-32.

16. Inada S, Koto T, Futami K, Arima S, Iwashita A. Evaluation of malignancy and the prognosis of esophageal cancer based on an immunohistochemical study (p53, E-cadherin, epidermal growth factor receptor). Surg Today. 1999:29:493-503.

17. Valizadeh A, Karayiannakis AJ, el-Hariry I, Kmiot W, Pignatelli M. Expression of E-cadherin-associated molecules (alpha-, beta-, and gamma-catenins and p120) in colorectal polyps. Am J Pathol. 1997;150:1977-84.

18. Takayama T, Shiozaki H, Shibamoto S, Oka H, Kimura Y, Tamura S, Inoue M, Monden T, Ito F, Monden M. Beta-catenin expression in human cancers. Am J Pathol. 1996;148:39-46.

19. Nakanishi Y, Ochiai A, Akimoto S, Kato H, Watanabe H, Tachimori Y, Yamamoto S, Hirohashi S. Expression of E-cadherin, alpha-catenin, beta-catenin and plakoglobin in esophageal carcinomas and its prognostic significance: immunohistochemical analysis of 96 lesions. Oncology. 1997;54:158-65.

20. Li G, Liu Y, Yin H, Zhang X, Mo X, Tang J, Chen W. E-cadherin gene promoter hypermethylation may contribute to the risk of bladder cancer among Asian populations. Gene. 2014:534:48-53.

21. Tryndyak VP, Beland FA, Pogribny IP. E-cadherin transcriptional downregulation by epigenetic and microRNA-200 family alterations is related to mesenchymal and drug-resistant phenotypes in human breast cancer cells. Int J Cancer. 2010:126:2575-83.

22. Saydam O, Shen Y, Wurdinger T, Senol O, Boke E, James MF, Tannous BA, Stemmer-Rachamimov AO, Yi M, Stephens RM, et al. Downregulated microRNA-200a in meningiomas promotes tumor growth by reducing E-cadherin and activating the Wnt/beta-catenin signaling pathway. Mol Cell Biol. 2009;29:5923-40

23. Marty-Santos $\mathrm{L}$, Cleaver O. Pdx1 regulates pancreas tubulogenesis and E-cadherin expression. Development. 2016;143:101-12.

24. Nakamura Y. The role of the adenomatous polyposis coli (APC) gene in human cancers. Adv Cancer Res. 1993;62:65-87.

25. Satoh S, Daigo Y, Furukawa Y, Kato T, Miwa N, Nishiwaki T, Kawasoe T, Ishiguro $\mathrm{H}$, Fujita $\mathrm{M}$, Tokino $\mathrm{T}$, et al. AXIN1 mutations in hepatocellular carcinomas, and growth suppression in cancer cells by virus-mediated transfer of AXIN1. Nat Genet. 2000;24:245-50.

26. Munemitsu S, Albert I, Souza B, Rubinfeld B, Polakis P. Regulation of intracellular beta-catenin levels by the adenomatous polyposis coli (APC) tumor-suppressor protein. Proc Natl Acad Sci U S A. 1995;92:3046-50.

27. Morin PJ, Sparks AB, Korinek V, Barker N, Clevers H, Vogelstein B, Kinzler KW. Activation of beta-catenin-Tcf signaling in colon cancer by mutations in beta-catenin or APC. Science. 1997:275:1787-90.

28. Rubinfeld B, Robbins P, El-Gamil M, Albert I, Porfiri E, Polakis P. Stabilization of beta-catenin by genetic defects in melanoma cell lines. Science. 1997:275:1790-2.

29. Powell SM, Papadopoulos N, Kinzler KW, Smolinski KN, Meltzer SJ. APC gene mutations in the mutation cluster region are rare in esophageal cancers. Gastroenterology. 1994;107:1759-63.

30. Choi YW, Heath El, Heitmiller R, Forastiere AA, Wu TT. Mutations in betacatenin and APC genes are uncommon in esophageal and esophagogastric junction adenocarcinomas. Mod Pathol. 2000;13:1055-9.

31. Kudo J, Nishiwaki T, Haruki N, Ishiguro H, Shibata Y, Terashita Y, Sugiura H, Shinoda N, Kimura M, Kuwabara Y, Fujii Y. Aberrant nuclear localization of beta-catenin without genetic alterations in beta-catenin or Axin genes in esophageal cancer. World J Surg Oncol. 2007;5:21.

32. Berx G, Staes K, van Hengel J, Molemans F, Bussemakers MJ, van Bokhoven A van Roy F. Cloning and characterization of the human invasion suppressor gene E-cadherin (CDH1). Genomics. 1995:26:281-9.

33. Kraus C, Liehr T, Hulsken J, Behrens J, Birchmeier W, Grzeschik KH, Ballhausen WG. Localization of the human beta-catenin gene (CTNNB1) to 3p21: a region implicated in tumor development. Genomics. 1994;23:272-4.

34. Williams JL, Greer PA, Squire JA. Recurrent copy number alterations in prostate cancer: an in silico meta-analysis of publicly available genomic data. Cancer Genet. 2014;207:474-88.

35. Chan MW, Hui AB, Yip SK, Ng CF, Lo KW, Tong JH, Chan AW, Cheung HY, Wong WS, Chan PS, et al. Progressive increase of genetic alteration in urinary bladder cancer by combined allelotyping analysis and comparative genomic hybridization. Int J Oncol. 2009;34:963-70.

36. Xu XL, Ling ZQ, Chen SZ, Li B, Ji WH, Mao WM. The impact of E-cadherin expression on the prognosis of esophageal cancer: a meta-analysis. Dis Esophagus. 2014:27:79-86.

37. Zeng R, Duan L, Kong YK, Wu XL, Wang Y, Xin G, Yang KH. Prognostic significance of beta-catenin expression in patients with esophageal carcinoma: a meta-analysis. Asian Pac J Cancer Prev. 2014;15:6103-8.

38. Di Bartolomeo M, Pietrantonio F, Pellegrinelli A, Martinetti A, Mariani L, Daidone MG, Bajetta E, Pelosi G, de Braud F, Floriani I, Miceli R. Osteopontin, 
E-cadherin, and beta-catenin expression as prognostic biomarkers in patients with radically resected gastric cancer. Gastric Cancer. 2015.

39. Liang Z, Sun XY, Xu LC, Fu RZ. Abnormal expression of serum soluble E-cadherin is correlated with clinicopathological features and prognosis of breast cancer. Med Sci Monit. 2014;20:2776-82.

40. Yang YL, Chen MW, Xian L. Prognostic and clinicopathological significance of downregulated E-cadherin expression in patients with non-small cell lung cancer (NSCLC): a meta-analysis. PLoS One. 2014;9:e99763.

41. Itami A, Shimada Y, Watanabe G, Imamura M. Prognostic value of p27(Kip1) and CyclinD1 expression in esophageal cancer. Oncology. 1999;57:311-7.

42. Shimada Y, Imamura M, Shibagaki I, Tanaka H, Miyahara T, Kato M, Ishizaki K. Genetic alterations in patients with esophageal cancer with short- and longterm survival rates after curative esophagectomy. Ann Surg. 1997;226:162-8.

43. Kato J, Kuwabara Y, Mitani M, Shinoda N, Sato A, Toyama T, Mitsui A, Nishiwaki T, Moriyama S, Kudo J, Fujii Y. Expression of survivin in esophageal cancer: correlation with the prognosis and response to chemotherapy. Int J Cancer. 2001;95:92-5.

44. Shibata Y, Haruki N, Kuwabara Y, Nishiwaki T, Kato J, Shinoda N, Sato A, Kimura M, Koyama H, Toyama T, et al. Expression of PTTG (pituitary tumor transforming gene) in esophageal cancer. Jpn J Clin Oncol. 2002;32:233-7.

45. Konishi S, Ishiguro H, Shibata Y, Kudo J, Terashita Y, Sugiura H, Koyama H, Kimura M, Sato A, Shinoda N, et al. Decreased expression of DFF45/ICAD is correlated with a poor prognosis in patients with esophageal carcinoma. Cancer. 2002;95:2473-8.

46. Sugito $N$, Ishiguro $H$, Kuwabara $Y$, Kimura M, Mitsui A, Kurehara $H$, Ando $T$, Mori R, Takashima N, Ogawa R, Fujii Y. RNASEN regulates cell proliferation and affects survival in esophageal cancer patients. Clin Cancer Res. 2006;12:7322-8

\section{Submit your next manuscript to BioMed Central and we will help you at every step:}

- We accept pre-submission inquiries

- Our selector tool helps you to find the most relevant journal

- We provide round the clock customer support

- Convenient online submission

- Thorough peer review

- Inclusion in PubMed and all major indexing services

- Maximum visibility for your research

Submit your manuscript at www.biomedcentral.com/submit

) Biomed Central 